\title{
Element uptake, accumulation, and resorption in leaves of mangrove species with different mechanisms of salt regulation
}

\author{
E. Medina ${ }^{1,3}$, W. Fernandez ${ }^{1}$, and F. Barboza ${ }^{2}$ \\ ${ }^{1}$ Centro de Ecología, Instituto Venezolano de Investigaciones Científicas, Caracas, Venezuela \\ ${ }^{2}$ Departamento de Biología, Facultad de Ciencias, Universidad del Zulia, Maracaibo, Venezuela \\ ${ }^{3}$ International Institute of Tropical Forestry, USDA Forest Service, Río Piedras, Puerto Rico \\ Correspondence to: E. Medina (emedina@ivic.gob.ve, medinage@gmail.com)
}

\begin{abstract}
Element uptake from substrate and resorption capacity of nutrients before leaf shedding are frequently species-specific and difficult to determine in natural settings. We sampled populations of Rhizophora mangle (salt-excluding species) and Laguncularia racemosa (salt-secreting species) in a coastal lagoon in the upper section of the Maracaibo strait in western Venezuela to estimate accumulation and resorption of mineral elements. Leaves collected fortnightly during 4 months within the rainy season were stratified as young, adult, old, and senescent. We measured changes in concentration of essential elements ( $, \mathrm{P}, \mathrm{S}, \mathrm{K}, \mathrm{Mg}, \mathrm{Ca}, \mathrm{Mn}$, $\mathrm{Fe}$ ) and $\mathrm{Na}$ (elemental analyzer and plasma spectrometer), leaf succulence (water/area), and specific leaf area (area/mass) and calculated relative resorption or accumulation of elements in senescent leaves before abscission. Succulence was similar in young leaves of both species and increased with age, more abruptly in $L$. racemosa. Concentrations of $\mathrm{N}, \mathrm{K}$, and $\mathrm{Mg}$ were higher in $R$. mangle, whereas those of $\mathrm{P}, \mathrm{Na}, \mathrm{Ca}$, and $\mathrm{S}$ were higher in $L$. racemosa. Concentration of $\mathrm{K}$ per unit leaf water decreased with age in both species; however, Na concentration in $R$. mangle remained at a similar level until increasing markedly in senescent leaves, whereas in L. racemosa it increased throughout the leaf lifespan. Relative changes based on leaf mass, leaf area, or whole leaf did not differ statistically. On a leaf mass basis both species showed resorption of C, N, P, and K and accumulation of $\mathrm{S}, \mathrm{Na}, \mathrm{Mg}, \mathrm{Ca}, \mathrm{Mn}$, and $\mathrm{Fe}$. However, R. mangle was more efficient restricting $\mathrm{Na}$ and $\mathrm{S}$ uptake, resorbing $\mathrm{P}$, and accumulating Fe than L. racemosa. The $\mathrm{P} / \mathrm{N}$ resorption ratio is $>1$ in $R$. mangle and $<1$ in L. racemosa. We conclude that those differences are related to higher root permeability to $\mathrm{Na}$ and $\mathrm{S}$ salts in the salt-secreting species and to higher P requirements of $R$. mangle compared to $L$. racemosa. Our results give a comprehensive picture of nutrient dynamics in the foliage of mangrove species with contrasting mechanisms of salt regulation.
\end{abstract}

1

\section{Introduction}

Mangrove communities dominated by Rhizophora mangle, a salt excluder sensu (Scholander et al., 1962), and Laguncularia racemosa, a salt-secreting species with succulent leaves (Biebl and Kinzel, 1965; Tomlinson, 1986; Lugo et al., 2007; Sobrado, 2004), occur in the northern coast of South America in contiguous areas under similar climatic, edaphic, and salinity conditions. Both species are tolerant of high soil interstitial water salinity but differ in their tolerance to flooding, presence of salt-secreting glands, and the nature of compatible solutes accumulated in their leaves (Tomlinson, 1986;
Medina et al., 2001). Co-occurrence of these species within the same natural setting provides an opportunity to conduct ecophysiological analyses to identify patterns of element uptake related to adaptation to saline environments and specific nutrient requirements.

In this paper we quantified differences between these two mangrove species, focusing on (a) variations in dimensions and elemental composition of leaves of increasing age as means to determine differences in nutrient requirements and (b) reliability of estimates of relative changes in element concentration based on leaf mass or area basis compared to 
whole leaf values when calculating net resorption from or accumulation in senescent leaves.

We tested a set of hypothesis using measurements of leaf elemental composition during the most favorable time of the year for leaf production.

1. The salt-secreting species takes up and accumulates in leaves larger quantities of $\mathrm{Na}$ and probably $\mathrm{S}$. We expect lower root permeability to $\mathrm{Na}$ in the salt-excluding species (Scholander, 1968). By analogy we expected that $\mathrm{S}$ uptake, the third most abundant element in sea water after $\mathrm{Na}$ and $\mathrm{Cl}$, might be also restricted by the salt excluder.

2. Succulence (water content per unit leaf area) development during aging in L. racemosa leaves (Biebl and Kinzel, 1965) is related to decreases in salt secretion capability. Continuous transport of $\mathrm{Na}$ from roots leads to concentration increase in the vacuoles of aging leaves resulting in succulence development (Flowers and Colmer, 2008).

3. Relative net change in essential element concentration before abscission (= element concentration in senescent leaf/element concentration in adult leaf) should be large and negative for phloem-mobile elements, such as $\mathrm{N}$, $\mathrm{P}, \mathrm{S}, \mathrm{K}$, and $\mathrm{Mg}$, and positive for elements with low phloem mobility, such as $\mathrm{Ca}, \mathrm{Fe}$, and $\mathrm{Mn}$. The $\mathrm{Na}$ net change values have to be positive in spite of its high phloem mobility because of its high concentration in the soil solution, its osmotic compensating role in leaf cells, and the lack of a sink in younger tissues.

4. Resorption values of $\mathrm{N}$ and $\mathrm{P}$ indicate specific requirements of those elements. Resorption of $\mathrm{N}$ and $\mathrm{P}$ before leaf abscission is considered an important conserving mechanism factor in trees (Vergutz et al., 2012), and the $\mathrm{N}$ : $\mathrm{P}$ resorption ratios are considered to be $<1$ in tropical vegetation, indicating a higher demand for $\mathrm{P}$ than $\mathrm{N}$ (Reed et al., 2012). We expected to have similar values for both species if their requirements were higher for $\mathrm{P}$ than for $\mathrm{N}$.

\section{Materials and methods}

\subsection{Study area}

Las Peonías lagoon has an extension of 612 ha and is located on the northwestern coast of the strait connecting the Maracaibo Lake with the Tablazo bay, between the cities of Maracaibo and Santa Cruz de Mara $\left(10^{\circ} 43^{\prime} 10^{\prime \prime}-10^{\circ} 45^{\prime} 50^{\prime \prime} \mathrm{N}\right.$; $71^{\circ} 35^{\prime} 02^{\prime \prime}-71^{\circ} 40^{\prime} 50^{\prime \prime} \mathrm{W}$ ) (Acevedo and Cañas, 1980). Within this area mangrove vegetation containing populations of Rhizophora mangle L. and Laguncularia racemosa (L.) Gaertn. cover about 80 ha (Galué and Nucete, 1982). The lagoon receives fresh water from seasonal watercourses and maritime waters from the Maracaibo Lake through semidiurnal tides. Lagoon turnover requires several tidal cycles for completion, therefore lagoon waters are brackish, promoting the establishment of halophytic species in the internal coastline. Surface runoff provides abundant supply of $\mathrm{N}$ and P (Soto, 1996).

The climate is semi-arid with a typical tropical pattern of rainfall distribution, showing a small rainfall peak in May and a larger one in October. Data from the station at Santa Cruz de Mara, about $2.5 \mathrm{~km}$ north of the center of the lagoon, indicate that annual rainfall averages $400 \mathrm{~mm}$, whereas mean annual Tank A potential evaporation reaches $1500 \mathrm{~mm}$. Air temperature averages $28.4^{\circ} \mathrm{C}$ with mean maximum of $33.4{ }^{\circ} \mathrm{C}$ and mean minimum of $23.4{ }^{\circ} \mathrm{C}$ (Acevedo and Cañas, 1980). Field work took place during the humid season (August-November).

We selected sites dominated by populations of $R$. mangle or $L$. racemosa along the internal coastline of the lagoon, located about $100 \mathrm{~m}$ from each other.

At each site we established five plots $(5 \mathrm{~m} \times 5 \mathrm{~m})$, separated $10 \mathrm{~m}$ from each other. In each plot we counted the number of trees and measured their diameter just below the first branch to calculate density and basal area of each population (Cintrón and Schaeffer-Novelli, 1984).

\subsection{Leaf, water, and sediment sampling}

Leaf sampling was stratified according to relative leaf age determined by their position in the branch as follows: young (Yo) leaves from the first or second pair, near full expansion; adult (Ad) leaves from the second or third pair, fully expanded; old (Ol) leaves from the third or fourth pair, generally thicker or more coriaceous than the previous type; and senescent ( $\mathrm{Se}$ ) leaves showing clear signs of chlorophyll loss, becoming yellow (Medina et al., 2010). The senescent leaves of both species reach this stage fully turgid, a characteristic of many mangrove species probably facilitating nutrients resorption before abscission. In each plot of both sites, leaves were collected fortnightly (eight sampling dates) between August and November (four replicates for Yo, Ad, and Ol leaves and eight replicates for Se leaves from three different trees). Leaves were transported to the laboratory in refrigerated boxes where they were cleaned gently with humid absorbent paper. Fresh mass and area were determined immediately afterwards, and the samples were dried in ventilated oven at $65^{\circ} \mathrm{C}$ for $72 \mathrm{~h}$. Succulence index was calculated as the water content per unit area expressed as $\mathrm{kg}$ water $\mathrm{m}^{-2}$ ([fresh mass - dry mass] / area). Specific leaf area (SLA) was calculated as the ratio of area/dry mass and expressed as $\mathrm{m}^{2} \mathrm{~kg}^{-1}$.

We collected four soil cores (10 cm diameter, $40 \mathrm{~cm}$ depth) from each plot at the beginning of collection period (20 per species). The plots were flooded during the whole collection period (August-November), and water samples were col- 
lected during each collection date in each plot at the contact with the sediments (ca. 10-20 cm depth).

\subsection{Chemical analyses}

Soils analyses shown in Table 2 were conducted at the Instituto para la Conservación del Lago de Maracaibo (ICLAM, Maracaibo, Venezuela). Procedures followed standard methodology as described in Page (1982).

Leaf samples replicates per plot were pooled to obtain one sample per age category and collection date from each species ( 4 ages +5 plots $\times 8$ dates) for elemental analyses. Analyses were conducted at the laboratory of the International Institute of Tropical Forestry, US Forest Service, San Juan, Puerto Rico.

Dried plant leaves were grounded (approximately to 18 mesh). Total carbon, nitrogen, and sulfur were determined by the macro dry combustion method using the LECO CNS2000 Analyzer (LECO Corp., 2003). For analyses of cations and $\mathrm{P}$, plant tissue samples were digested in concentrated $\mathrm{HNO}_{3}$ and $\mathrm{H}_{2} \mathrm{O}_{2}(30 \%)$. This wet oxidation method uses open vessels and a block digester and is a modified version of the digestion method recommended by Schulte (1985). The concentration of $\mathrm{Na}, \mathrm{K}, \mathrm{Mg}, \mathrm{Ca}, \mathrm{Fe}, \mathrm{Mn}$, and $\mathrm{P}$ in the resulting digests was analyzed simultaneously in a Spectro ICP emission spectrometer model Ciros CCD. Each analysis batch carried a blank and one or more certified plant tissue reference materials of known concentration to evaluate the recovery of each element determined. A subsample was oven dried at $105^{\circ} \mathrm{C}$ for $24 \mathrm{~h}$ to calculate a moisture factor for each sample and then placed in a muffle furnace at $490^{\circ} \mathrm{C}$ to determine ash content.

\subsection{Statistical analysis}

The leaf traits (mass, area, succulence, and leaf mass / area ratio) were analyzed using a mix model considering fixed effects (species, leaf age, and harvest), and random effects (within plots variation) using the residual maximum likelihood method (JMP, 2002, p. 254). Averages per species and dates of elemental concentrations were compared using analysis of variance and an a posteriori Tukey-Kramer HSD test. For smaller data sets (plot structure and soils) we used a nonparametric test (Wilcoxon/Kruskal-Wallis). All statistical analyses were conducted using the JMP 8.0 statistical program (www.sas.com).

\section{Results}

\subsection{Population structure and characterization of substrate sediments}

Average diameter at breast height and basal area of $R$. mangle population were about 3 times larger, while tree density was 3 times smaller, than those of L. racemosa (Table 1).
Table 1. Population structure of the mangrove plots used for leaf collections. Sample size: five plots, each of $25 \mathrm{~m}^{2}$. DBH is diameter at breast height.

\begin{tabular}{lrrr}
\hline Community & $\begin{array}{r}\text { Average DBH } \\
\mathrm{cm}\end{array}$ & $\begin{array}{r}\text { Density } \\
\text { ind./0.1 ha }\end{array}$ & $\begin{array}{r}\text { Basal area } \\
\mathrm{m}^{2} / 0.1 \text { ha }\end{array}$ \\
\hline $\begin{array}{l}\text { Laguncularia racemosa } \\
\text { Rhizophora mangle }\end{array}$ & 3.18 & 1088 & 0.98 \\
\hline ANOVA F & 9.96 & 336 & 3.14 \\
$P<0.01$ & 311 & 28.3 & 31.7 \\
Wilcoxon/Kruskal-Wallis & $<0.01$ & $<0.01$ & \\
Z & & & \\
$P$ & 2.51 & 2.52 & 2.51 \\
& 0.01 & 0.01 & 0.01 \\
\hline
\end{tabular}

The smaller basal area of the L. racemosa population may indicate a younger developmental stage, but we do not have information to confirm this. Nevertheless, both populations were flowering and reproducing actively, and we assumed that trees were functioning as mature adults in each population.

Average sediment composition showed higher values of organic matter, $\mathrm{N}$, and $\mathrm{K}$ but lower values of $\mathrm{Ca}$ in the $L$. racemosa site (Table 2). Levels of $\mathrm{N}$ and $\mathrm{P}$ appeared to be high enough to discard nutrient limitation for plant growth. Soil conductivity ( $1: 5$ extract) indicated conditions of moderate salinity throughout the measuring period. The salinity of lagoon water varied little during the study. Standing waters averaged $14 \%$ o for both sites $(n=40 /$ site), varying from 8 to $24 \%$, indicating that the populations studied were under moderate salt stress during the sampling period.

\subsection{Leaf size, specific leaf area, and succulence}

As expected, leaf traits varied significantly between species and leaf age, whereas the plots within each population did not add significant variance to the traits averages per harvest. However, harvests also differed significantly for both species; therefore we did not average the values for the whole sampling period but did describe the observed trends. The full data set and the results of the model are available upon request. Leaf mass and area were larger and heavier in $R$. mangle compared to $L$. racemosa throughout the sampling period and showed distinct patterns in each species (Fig. 1). $R$. mangle area and mass of the Yo, Ad, and Ol leaf age categories decreased until the fourth harvest and then increased markedly. L. racemosa variations were less pronounced, with a slight tendency to increase after the fifth harvest. Patterns of change in leaf mass and area were linear and highly significantly correlated in both species ( $R$. mangle: $n=2632$, $R_{\text {adjusted }}^{2}=0.76 ;$ L. racemosa: $\left.n=2392, R_{\text {adjusted }}^{2}=0.71\right)$.

The SLA in $R$. mangle showed the expected pattern of increase from Yo to $\mathrm{Ol}$ leaf age categories and a strong increase in the Se category (Fig. 2). In this species SLA values increased markedly in the fourth-sixth harvest, particularly in 
Table 2. Average composition of sediments under communities of Laguncularia racemosa and Rhizophora mangle in Laguna Las Peonías: samples $0-40 \mathrm{~cm}$ depth, $n=5$ per site, standard deviation in parentheses. $\mathrm{pH}$ and conductivity measured in a $1: 5$ soil-water proportion.

\begin{tabular}{lrrr}
\hline & Laguncularia & Rhizophora & Wilcoxon/Kruskal-Wallis \\
\hline $\mathrm{pH}$ & $7.9(0.1)$ & $8.0(0.1)$ & 0.18 \\
Conductivity & $4.4(0.7)$ & $5.4(2.3)$ & 0.83 \\
mmhos/cm & & & \\
Organic matter \% & $6.2(2.3)$ & $1.5(0.4)$ & $\mathbf{0 . 0 1}$ \\
\hline Elements in mmol kg & & & \\
$\mathrm{N}$ & $9.3(3.1)$ & $6.3(2.7)$ & 0.09 \\
$\mathrm{P}$ & $1.7(0.1)$ & $1.7(0.1)$ & 0.30 \\
$\mathrm{~K}$ & $93.8(24.8)$ & $31.3(3.8)$ & $\mathbf{0 . 0 1}$ \\
$\mathrm{Na}$ & $486(136)$ & $371(222)$ & 0.40 \\
$\mathrm{Ca}$ & $8.9(4.8)$ & $78.1(44.9)$ & $\mathbf{0 . 0 1}$ \\
$\mathrm{Mg}$ & $190(3.2)$ & $189(13.3)$ & 0.68 \\
\hline
\end{tabular}

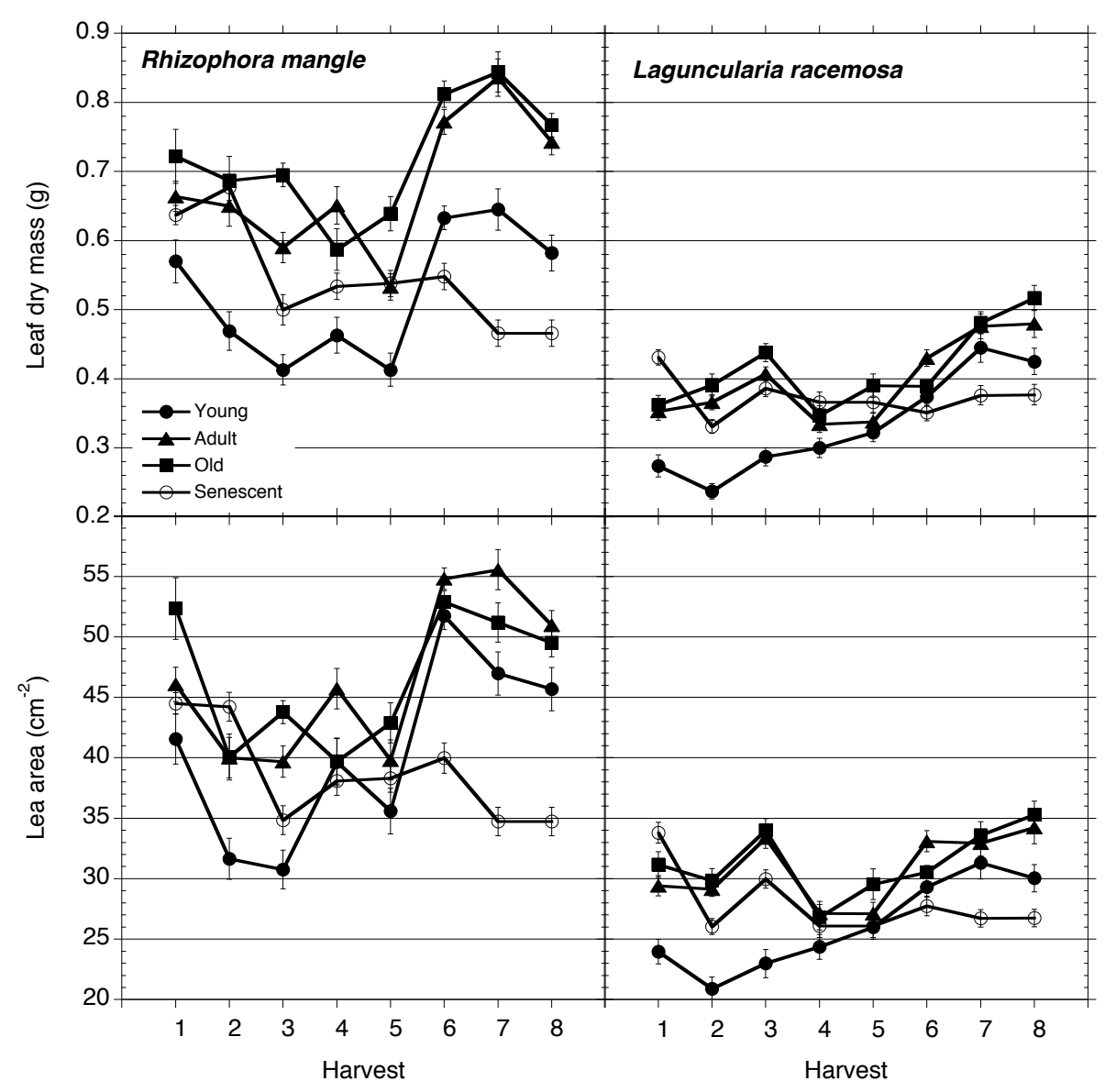

Figure 1. Variations in leaf mass and area measured in leaf samples during sequential harvests. Each point represents the average \pm s.e. of 60 leaves (young to old) or 120 leaves (senescent). Leaf traits differed significantly between species, age categories, and harvests.

the Yo category, indicating the production of new leaves. In L. racemosa the pattern of variation of SLA with leaf age was not discernible, but it showed a general tendency to decrease from the first to the third harvest, remaining similar until the sixth harvest and then decreasing in the last two harvests.
The largest interspecific differences were observed in the pattern of succulence measured during the sampling period (Fig. 2). R. mangle succulence increased from the Yo to Se categories and was lower in the fourth and fifth harvests. In L. racemosa, succulence increased markedly from the Yo to 


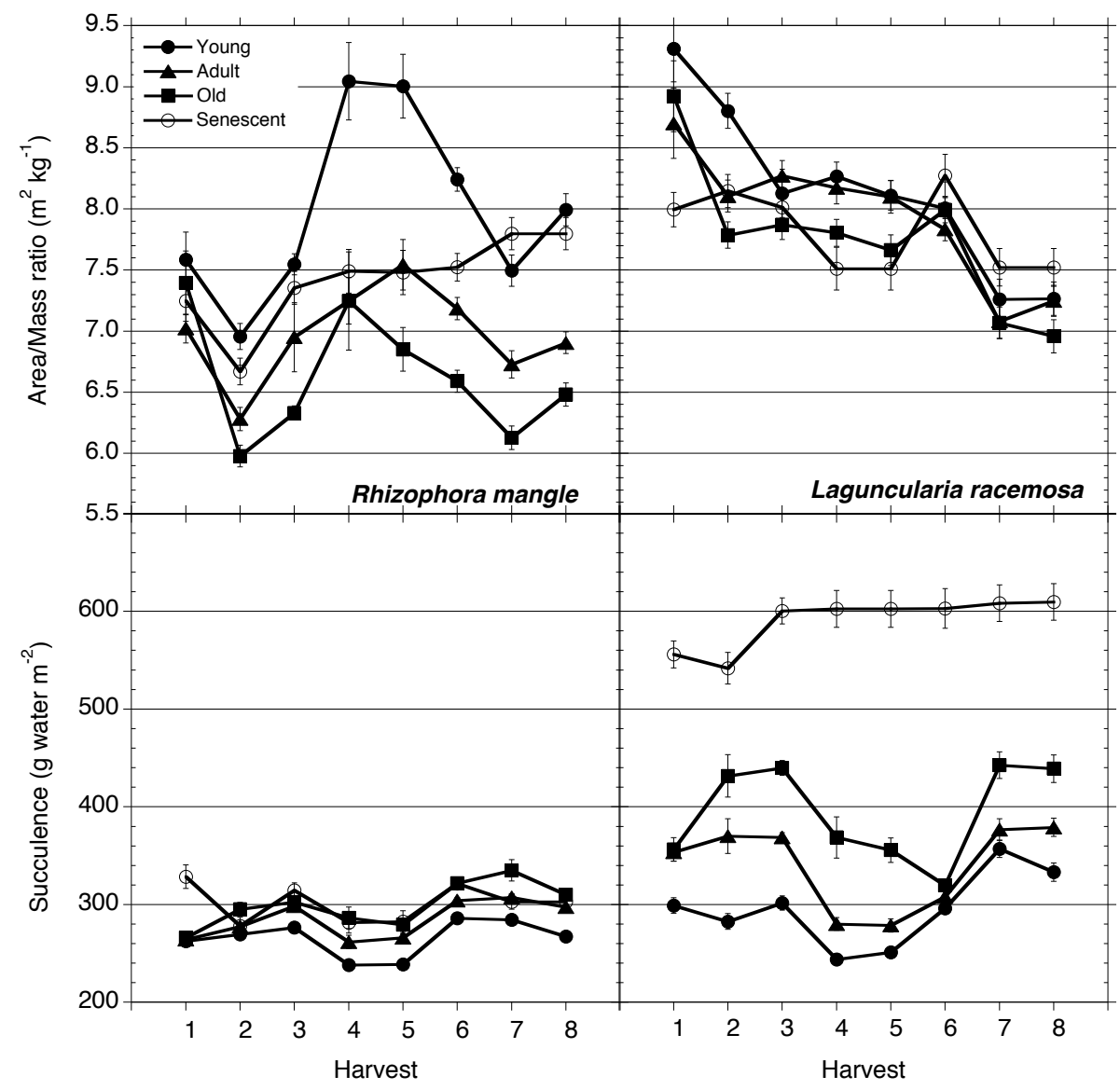

Figure 2. Variations in SLA and succulence indices measured in leaf samples during sequential harvests. Each point represents the average \pm s.e. of 60 leaves (young to old) or 120 leaves (senescent). Leaf traits differed significantly between species, age categories, and harvests.

Se categories, reaching values around $600 \mathrm{~g}$ water $\mathrm{m}^{-2}$ leaf area in senescent leaves.

\subsection{Patterns of element concentration change with leaf age}

Carbon and $\mathrm{N}$ concentrations per unit dry mass were significantly higher in $R$. mangle for all leaf stages, and $\mathrm{N}$ decreased significantly in $\mathrm{Ol}$ and Se leaves of both species (Fig. 3). Phosphorus decreased markedly with leaf relative age in both species, and its concentration was always higher in L. racemosa. In contrast, $\mathrm{S}$ concentration increased with age in both species but was more than doubly higher for all leaf categories in $L$. racemosa. Within the non-metallic elements, the order of concentrations on a molar basis was $\mathrm{C} \gg \mathrm{N}>\mathrm{S} \gg \mathrm{P}$.

Within the cations, $\mathrm{K}$ behaved similarly to $\mathrm{P}$ but its concentration was significantly higher in $R$. mangle $\mathrm{Ad}, \mathrm{Ol}$, and Se leaves (Fig. 4). Sodium concentrations increased with age in both species and were larger in L. racemosa. The Na / K ratio in $L$. racemosa increased from ca. 4 in Yo leaves up to 35 in Se leaves, whereas in $R$. mangle these ratios had a smaller range from 3 to 8 . Calcium increased with leaf age and was significantly more concentrated in L. racemosa. Magnesium was significantly higher in $R$. mangle but the concentration by mass remained similar from Yo to $\mathrm{Ol}$ leaves and increased significantly in Se leaves in both species. In $R$. mangle the concentrations of $\mathrm{Fe}$ and $\mathrm{Mn}$ were several times higher than in L. racemosa and increased with age only in the former (Fig. 4).

Uptake of $\mathrm{Na}$ and $\mathrm{S}$ in both species followed a similar pattern. Sodium concentrations were several times higher than $\mathrm{S}$ concentrations and were significantly correlated. However, $\mathrm{Na}$ concentrations explained nearly $60 \%$ of the variance of $\mathrm{S}$ concentration in L. racemosa $\left(R_{\text {adjusted }}^{2}=0.597 ; n=158\right)$ but only $14 \%$ in $R$. mangle $\left(R_{\text {adjusted }}^{2}=0.136 ; n=156\right)$.

The water content per unit dry mass increased markedly in $L$. racemosa but varied little in leaves of $R$. mangle (Fig. 5a). The K concentration per unit leaf water decreased with age in both species but its concentration was lower in L. racemosa at all leaf stages (Fig. 5b). Sodium concentration per unit leaf water increased consistently with age by L racemosa, whereas in $R$. mangle it remained constant until increasing significantly at the Se stage (Fig. 5c). 

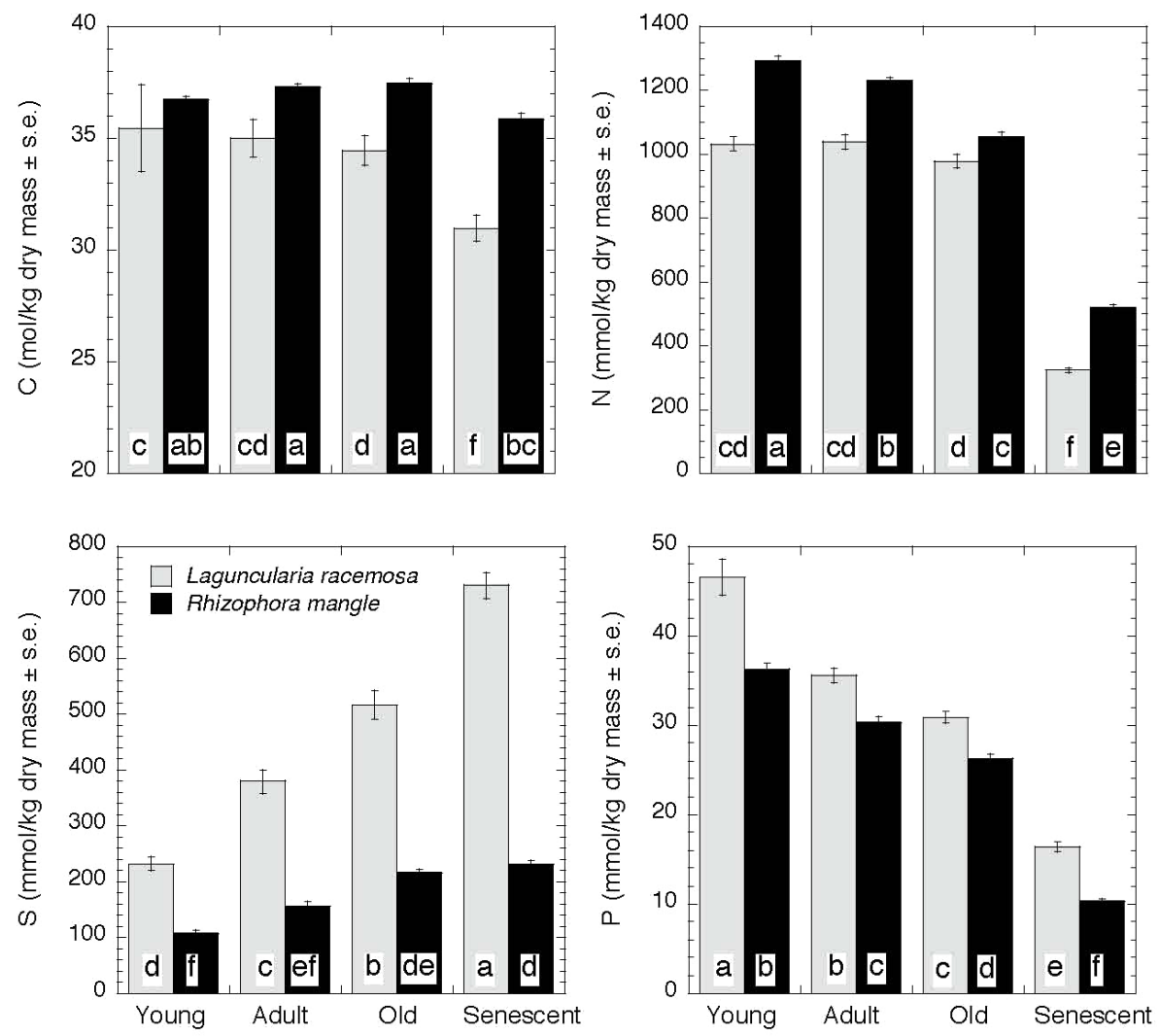

Figure 3. Changes in concentration of non-metallic elements with relative leaf age in L. racemosa and R. mangle. Columns sharing the same letter do not differ statistically (Tukey-Kramer HSD test, $P=0.05$ ).

\subsection{Changes in leaf elemental concentrations before shedding}

Relative element concentration change based on whole leaf mass, unit leaf mass, and unit leaf area in both species gave the same expected pattern of resorption for the phloem mobile elements $\mathrm{C}, \mathrm{N}, \mathrm{P}, \mathrm{K}$, and accumulation of the cations $\mathrm{Ca}, \mathrm{Mn}$, and $\mathrm{Fe}$ with low or intermediate phloem mobility (Fig. 6). In spite of their high phloem mobility $\mathrm{Mg}$ was slightly accumulated in both species, whereas $\mathrm{Na}$ and $\mathrm{S}$ showed relative changes around 0.5 in $R$. mangle and around 1 in $L$. racemosa. Compared to whole leaf values, relative changes on leaf mass or area tended to overestimate accumulation and underestimate resorption, but differences were not always significant. This pattern was more accentuated in $R$. mangle than in L. racemosa. This is due to the smaller reduction in leaf mass and area observed in passing from the Ad to the Se stages in L. racemosa compared to $R$. mangle (Fig. 1).

Nitrogen resorption in L. racemosa was significantly higher and $\mathrm{P}$ resorption significantly lower than in $R$. mangle.

\section{Discussion}

The conditions of moderate salinity stress and availability of fresh water during the rainy season provided an appropriate framework for the comparison of the element composition in leaves of $R$. mangle and L. racemosa. Plants were producing leaves continuously and showed normal phenological behavior regarding flowering and fruiting.

During the sampling period leaf mass, area, and the succulence and SLA indices varied significantly between harvests indicating that leaf categories were not equivalent at each sampling time. This is probably the result of production of new leaves during the collection period. From the SLA values it could be inferred that $R$. mangle, and to a certain extent also L. racemosa, produced new leaves between the third and the sixth harvests. In the latter species relatively younger leaves predominated in the canopy at the beginning of the sampling period as indicated by the continuous decrease in SLA of the Yo and Ad leaf categories. These results emphasize the need to conduct leaf morphological analyses on tagged leaves of known age that are measured repeatedly during several months.

The course of succulence values confirmed studies on the physiology and anatomy of these species. The salt-secreting 

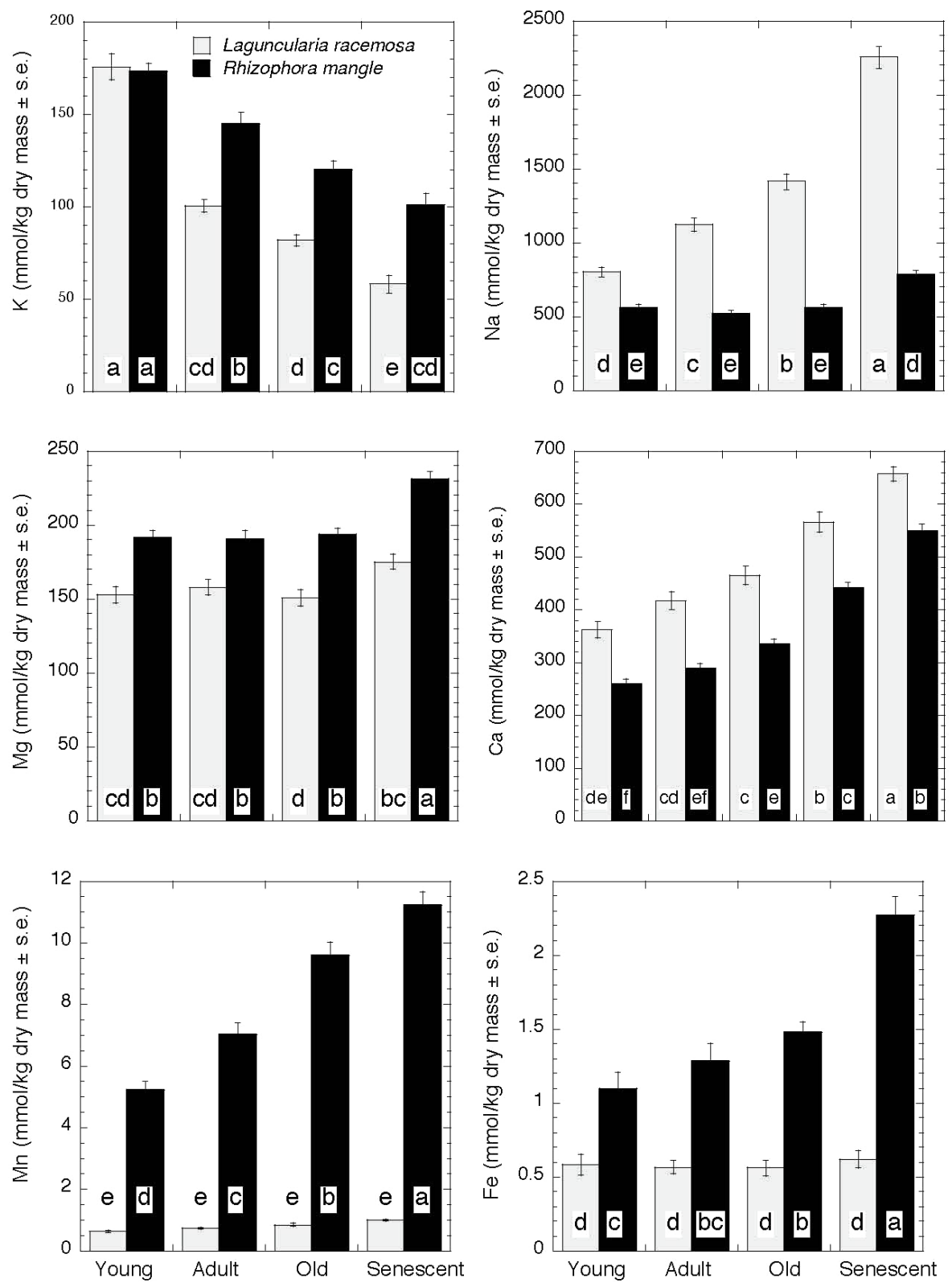

Figure 4. Changes in concentration of metallic elements with relative leaf age in L. racemosa and $R$. mangle. Columns sharing the same letter do not differ statistically (Tukey-Kramer HSD test, $P=0.05$ ).

species $L$. racemosa developed a high degree of succulence, particularly during the transition of Ad to Se leaves.

Our results show that both mangrove populations had a sufficient supply of $\mathrm{N}$ and $\mathrm{P}$ as revealed by the leaf concentrations of these elements. In the case of $R$. mangle, $\mathrm{N}$ and $\mathrm{P}$ concentrations were higher than values reported for mangroves in the Caribbean (Feller et al., 2003; Lin and Sternberg, 2007; Barboza et al., 2006; Lugo et al., 2007; Medina et al., 2010) but similar to those of tall mangroves on nutrientrich sediments in the Bragança peninsula in Brazil (Medina et al., 2001). In addition, $R$. mangle was more efficient in taking up $\mathrm{K}$ and $\mathrm{Mg}$ and rejecting $\mathrm{Na}$ from the root environment than $L$. racemosa. This may increase salinity tolerance in $R$. mangle because it results in more favorable $\mathrm{K} / \mathrm{Na}$ ratios for physiological function (Marschner, 1995; Flowers and Colmer, 2008). In contrast, L. racemosa had larger concentrations of $\mathrm{Na}, \mathrm{S}$, and $\mathrm{Ca}$ but lower concentrations of $\mathrm{Mg}$. These differences point to diverging physiological properties at the root level related to the salt exclusion from root tissues ( $R$. mangle) and capacity for salt secretion through salt glands in the leaves (L. racemosa). Scholander et al. (1962) distinguished between salt-excluding and salt-secreting man- 

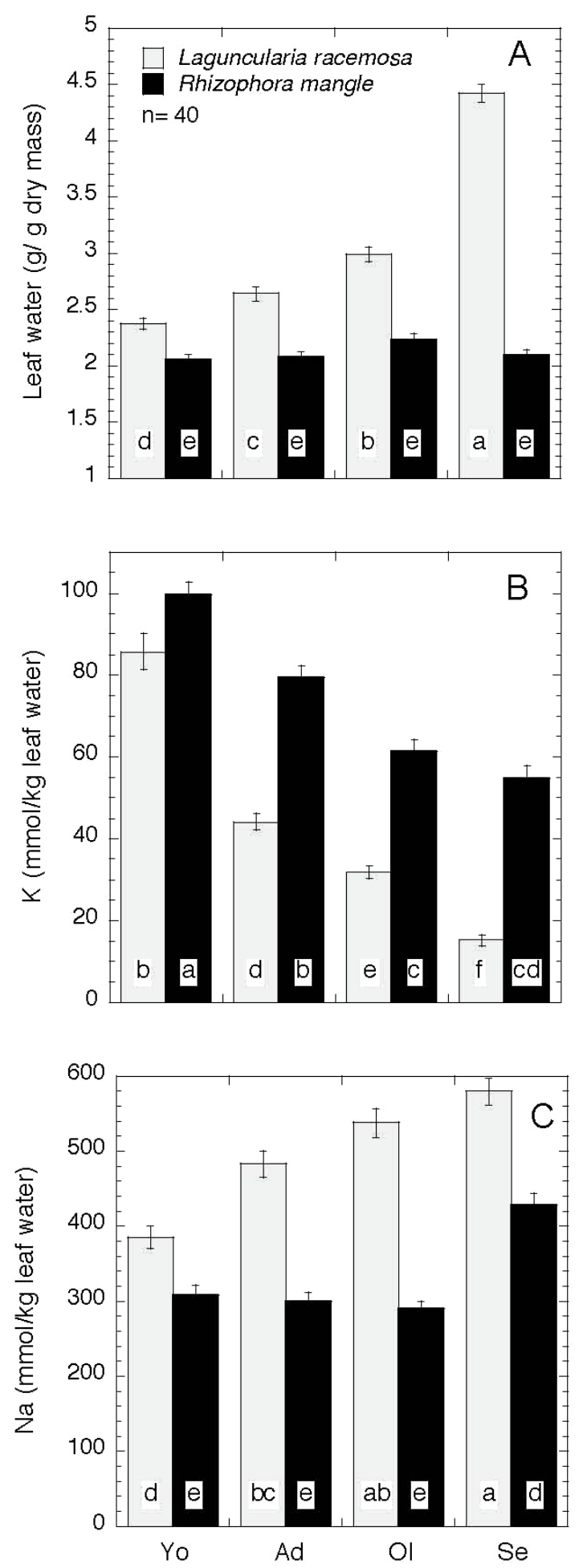

Figure 5. Changes of leaf content ( $\mathrm{g}$ water $\mathrm{g}^{-1}$ dry mass) and the concentration of soluble ions $(\mathrm{K}$ and $\mathrm{Na}$ ) per unit leaf water $\left(\mathrm{mmol} \mathrm{kg}{ }^{-1}\right.$ leaf water) with relative leaf age. Columns sharing the same letter do not differ statistically (Tukey-Kramer HSD test, $P=0.05)$. grove species and showed that salt-secreting species, such as Avicennia marina, had higher concentrations of $\mathrm{NaCl}$ in their xylem sap than salt excluders, such as Rhizophora mucronata.

Biebl and Kinzel (1965) described glandular structures in the lamina of L. racemosa leaves that later have been shown to be capable of secreting salt (Sobrado, 2004), at least in young and mature leaves (Francisco et al., 2009). Succulence development with leaf age is a consequence of $\mathrm{Na}$ accumulation in older leaves (Biebl and Kinzel, 1965), and our results show that succulence increased more rapidly between the old and senescent stage of the leaves.

The concentration per unit of leaf water of ions not related to structural compounds in the cell $(\mathrm{K}$ and $\mathrm{Na}$ ) reveals the relative efficiency of the mechanisms preventing salt accumulation in these mangroves. Prevention of $\mathrm{Na}$ uptake at the root level apparently predominates in $R$. mangle, and salt secretion and succulence occurs only in L. racemosa leaves. In R. mangle, Na concentration in leaf water remained nearly constant until the leaf Se stage, whereas in L. racemosa it increased strongly from the Yo to Se stages. Our interpretation is that in younger leaves salt-secreting glands are active, counteracting partially salt accumulation, but secretion stops in old leaves, resulting in a rapid increase in salt concentration accompanied by water uptake. Although $\mathrm{Na}$ is highly mobile in the phloem, it can be transported to the roots but not into growing tissues (Marschner, 1995, p. 93). Transport to the roots is probably restricted due to the high salinity of the mangrove soils.

The behavior of $\mathrm{K}$ concentration per unit leaf water has a different explanation. Potassium concentration decreased with age in both species, much more rapidly in L. racemosa, probably due to the large increase in the amount of leaf water per unit dry mass. The reduction in concentration points to lower net transport rates into the leaves in a process probably related to the role of $\mathrm{K}$ in the transport of nitrate from roots to leaves (Marschner, 1995, p. 197). Nitrate is transported in the xylem with $\mathrm{K}$ as a counterion, and it is probably preferentially transported to actively growing tissues (leaves and shoots) causing a decrease of supply into older leaves.

From an analysis of salt accumulation in leaves of saltexcluding and salt-secreting mangroves, Cram et al. (2002) concluded that, in general, mangrove leaves remain as a sink for $\mathrm{Na}$ throughout their lifetime, a fact confirmed in this paper. However, our results contradict their statement that there is no burst of salt accumulation at senescence, that yellow leaves do not have higher $\mathrm{Na}$ concentration than old green ones, and that salt-secreting species show smaller changes in mature leaf $\mathrm{Na}$ content.

Capacity for resorption of nutrients from senescing leaves is considered to be the main component of nutrient useefficiency for organic matter production (Chapin, 1980; Killingbeck, 1996; Wang et al., 2003). Nutrient resorption before leaf shedding is an important index related to nutrient use-efficiency (Aerts, 1996), but its measurement is dif- 


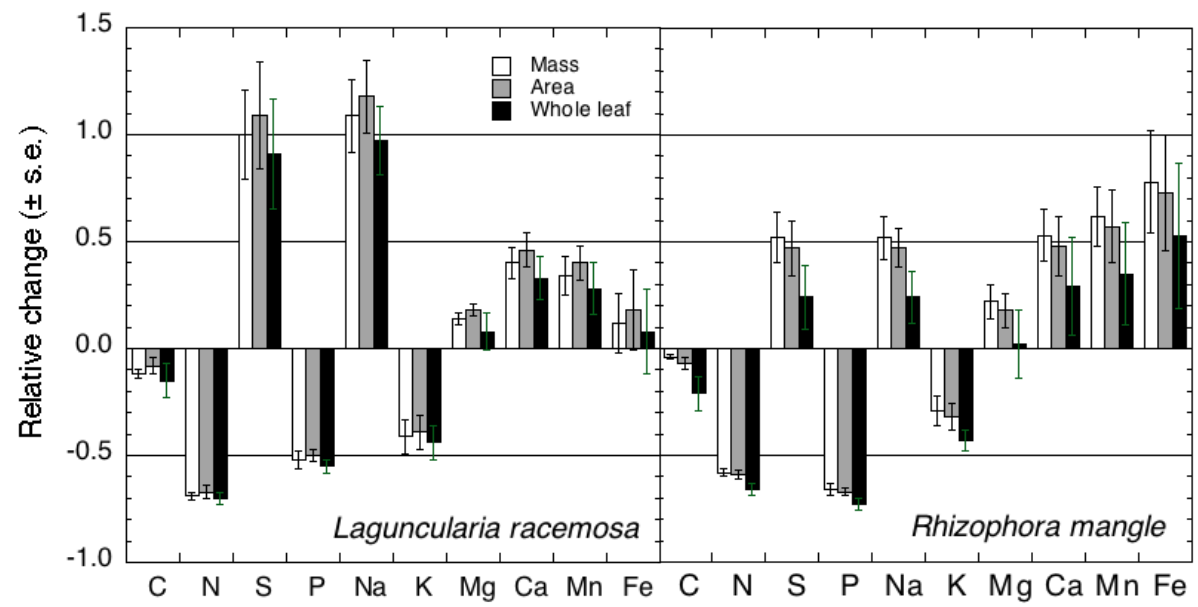

Figure 6. Relative change of element concentration from adult to senescent leaves calculated on a leaf mass, leaf area, and whole leaf basis. Values are estimated as the deviation from unity of the ratio of element concentration in senescent and adult leaves and represent the average of eight sequential harvests, each constituted by four-eight leaf replicates from three trees in five plots per site.

ficult because measurements of nutrient concentrations are conducted on different leaves (adult and senescent) and the unit of reference (mass or area) does not remain constant as the leaves age (Lin and Wang, 2001; Heerwarden et al., 2003; Vergutz et al., 2012). Our study shows significant reductions of leaf area and mass in both species when passing from the old to the senescent stage, as reported before for three non-salt-secreting mangrove species in China by Lin and Wang (2001). These reductions may cause underestimation of resorption $(\mathrm{N}, \mathrm{P}, \mathrm{K})$ and overestimation of accumulation ( $\mathrm{S}, \mathrm{Na}, \mathrm{Ca}, \mathrm{Mn}, \mathrm{Fe}$ ) when relative changes are calculated on a mass or an area basis compared to those calculated on a whole leaf basis.

The analysis of published resorption values for $\mathrm{N}$ and $\mathrm{P}$ corrected for changes in leaf mass during senescence showed that for the group of tropical deciduous and evergreen woody plants the general pattern is of higher resorption of $\mathrm{P}$ compared to N (Vergutz et al., 2012); this pattern is confirmed for $R$. mangle by the present study and by other reports in the literature (Feller et al., 2003, Lin and Sternberg, 2007, Lugo et al., 2007, Medina et al., 2010) but is opposite to the report of Lin and Wang (2001) on three mangrove species belonging to the tribe Rhizophoreae. In $L$. racemosa, resorption was larger for $\mathrm{N}$ than for $\mathrm{P}$, in a similar fashion as reported for Kandelia candel by Wang et al. (2003). We suggest that higher resorption of $\mathrm{P}$ compared to $\mathrm{N}$ points to the higher requirement of $\mathrm{P}$ by Rhizophora species than by other mangrove species.

Higher availability of $\mathrm{N}$ and $\mathrm{P}$, reflected also in higher concentrations of those elements in leaf tissue, was expected to be correlated with reduction of relative resorption (Chapin, 1980), as shown in fertilization experiments on dwarf mangroves of Belize (Feller et al., 2003). However, comparison of mangrove forests differing in the amount of available $\mathrm{P}$ and $\mathrm{N}$ as judged by the concentrations of those elements in leaves do not support this statement. On a mass basis dwarf and tall mangroves in Belize, differing in $\mathrm{P}$ limitation, had $80 \%$ P resorption whereas N ranged from 49 to $69 \%$ (Feller, 2003). In South Florida, Lin and Sternberg (2007) reported resorption of $46 \%$ for $\mathrm{N}$ and $54 \%$ for $\mathrm{P}$ in tall mangroves (less limited by $\mathrm{P}$ ), whereas dwarf mangroves had reduced $\mathrm{N}(40 \%)$ and increased $\mathrm{P}(68 \%)$ resorption values. In dwarf mangroves on peat with limited tides in Puerto Rico, Medina et al. (2010) observed a similar behavior to those in Belize. Our site in Las Peonias was clearly not limited by $\mathrm{N}$ or $\mathrm{P}$ supply, but resorption values were within the range of those measured in nutrient limited systems.

The Killingbeck's indices (1996) indicate complete resorption of $\mathrm{P}$ but not of $\mathrm{N}$ in $R$. mangle, whereas the opposite was the case for $L$. racemosa. Together with the resorption values of $\mathrm{N}$ and $\mathrm{P}$ this comparison points to higher $\mathrm{P}$ requirement by $R$. mangle.

The resorption factor for $\mathrm{K}$ was similar for both species, at the same level as reported by Vergutz et al. (2012) for woody tropical species, and in agreement with the high phloem mobility of this cation (Marschner, 1995). In both species $\mathrm{Mg}$ was accumulated on a mass and area basis up to $20 \%$, whereas $\mathrm{Ca}$ was accumulated in both species by a factor as high as $50 \%$, as expected from an element with low phloem mobility. Our results do not agree with the resorption values for Ca reported by Vergutz et al. (2012). We have no comparative data for resorption of $\mathrm{Mn}$ and Fe. The former is accumulated in leaves of both species by a factor similar to that of $\mathrm{Ca}$, confirming the low phloem mobility of this element (Marschner, 1995), although its concentration in $R$. mangle leaves is 1 order of magnitude larger. Iron, an element relatively mobile in phloem, was accumulated markedly only in $R$. mangle. The physiological mechanisms to explain these 
behaviors include the interaction between uptake through the roots and deposition in leaf tissues and subsequent resorption. It seems that during leaf aging L. racemosa restricts partially the uptake of $\mathrm{Fe}$ and maintains its concentration after full leaf expansion, indicating similar rates of transport and remobilization. In the case of $R$. mangle, rate of transport to the leaf appears to be higher than remobilization at the end of the leaf lifespan.

Uptake and accumulation of the elements' determinant of salinity in coastal environments ( $\mathrm{Na}$ and $\mathrm{S}$ ) contrast significantly between the salt-excluder, $R$. mangle, and the saltsecretor, L. racemosa. Both species take up more $\mathrm{Na}$ than $\mathrm{S}$, but in L. racemosa concentrations of both elements are several times higher at all leaf stages. It seems that restriction of salt uptake through the roots in $R$. mangle includes both $\mathrm{Na}$ and $\mathrm{S}$ (probably in the form of $\mathrm{SO}_{4}$ ion).

Structural development of mangrove communities in Las Peonías is much lower than in other sites within the Maracaibo strait area. The $R$. mangle forest in Punta de Palmas had basal areas 10 times larger than those recorded for Las Peonías (Barboza et al., 2006). Las Peonías is a coastal lagoon receiving nutrient-rich runoff from the surroundings so that there are no nutrient limitations for plant growth, and our measurements suggest that there are no strong salinity stress. The smaller structural development in Las Peonías may be a consequence of diminished water flow to and from the Tablazo bay, leading to water stagnation and hypoxia in the rooting environment. Although both L. racemosa and $R$. mangle possess roots densely covered by lenticels, gas exchange through those structures is strongly dependent on tidal forces that pushes air in and out of them, as shown by Scholander et al. (1955) in Avicennia sp. roots.

\section{Conclusions}

- Leaf accumulation or resorption factors based on leaf mass or area leads to over- or underestimations compared to values based on whole leaves, because leaf dimensions do not remain constant until abscission.

- Resorption of $\mathrm{P}$ was significantly higher than resorption of $\mathrm{N}$ in $R$. mangle, whereas the opposite was the case for L. racemosa. Together with Killingbeck's index, the higher $\mathrm{P}$ requirement of $R$. mangle appears to be confirmed.

- K concentration per unit leaf water decreased with age in both species, but absolute concentrations were lower and rates of concentration decrease were higher in $L$. racemosa due to succulence development.

- Rhizophora mangle regulates $\mathrm{Na}$ uptake into leaves until Se stage, but in L. racemosa $\mathrm{Na}$ concentration increased continuously until leaf abscission.
- Laguncularia racemosa counteracted increases in $\mathrm{Na}$ concentration per unit leaf water through water uptake and retention in vacuoles (succulence). The larger increase of succulence between the $\mathrm{Ol}$ and Se stages suggests reduced glandular activity at the end of the leaf life span.

- Both species accumulate more $\mathrm{Na}$ than $\mathrm{S}$, but concentrations of both elements are several times larger in $L$. racemosa at all leaf stages. Sodium and $\mathrm{S}$ accumulations were highly correlated in L. racemosa but less so in $R$. mangle.

- Mn and Fe concentrations were several times larger in $R$. mangle at all leaf stages.

Author contributions. E. Medina designed and supervised the field study, supervised leaf analyses, and wrote the paper with contributions of the coauthors; W. Fernandez conducted the field sampling and did the soil analyses at ICLAM; F. Barboza coordinated the field and laboratory work in Maracaibo.

Acknowledgements. Thanks to the Instituto para la Conservación del Lago de Maracaibo, Edo. Zulia, Venezuela, for the analysis of water and sediment samples; to International Institute of Tropical Forestry (USDA Forest Service) in Río Piedras, Puerto Rico, for the analyses of leaf samples; and to the Center of Applied Tropical Ecology at the University of Puerto Rico, Río Piedras, for providing technical assistance. Thanks as well as to the reviewers of Web Ecology for their critical analysis of the paper leading to improvements of the statistical treatment of the data.

Edited by: J. Stadler

Reviewed by: R. Brandl and one anonymous referee

\section{References}

Acevedo, L. and Cañas, H.: Estudio del régimen hidráulico de la laguna las Peonías, Trabajo especial de grado, Universidad del Zulia, Maracaibo, Venezuela, 1980.

Aerts, R.: Nutrient resorption from senescing leaves of perennials: Are there general patterns?, J. Ecol., 84, 597-608, 1996.

Barboza, F., Barreto, M. B., Figueroa, V., Francisco, A. M., Gonzalez, A., Lucena, L., Mata, K. Y., Narváez, E., Ochoa, E., Parra, L., Romero, D., Sanchez, J., Soto, M. N., Vera, A. J., Villarreal, A. L., Yabroudi, S. C., and Medina, E.: Desarrollo estructural y relaciones nutricionales de un manglar ribereño bajo clima semiárido, Ecotropicos, 19, 13-29, 2006.

Biebl, R. and Kinzel, H.: Blattbau und Salzhaushalt von Laguncularia racemosa (L.) Gaertn. f. und anderer Mangrovebäume auf Puerto Rico, Österr. Bot. Z., 112, 56-93, 1965.

Chapin, F. S.: The mineral nutrition of wild plants, Ann. Rev. Ecol. Syst., 11, 233-260, 1980. 
Cintrón, G. and Schaeffer-Novelli, Y.: Methods for studying mangrove structure, in: the Mangrove Ecosystem: Research Methods, edited by: Snedaker, S. C. and Snedaker, J. G., UNESCO, Bungay, UK, 91-113, 1984.

Cram, W. J., Torr, P. G., and Rose, D. A.: Salt allocation during leaf development and leaf fall in mangroves, Trees, 16, 112-119, 2002.

Feller, I. C., McKee, K. L., Whigham, D. F., and O’Neill, J. P.: Nitrogen vs. Phosphorus limitation across an ecotonal gradient in a mangrove forest, Biogeochemistry, 62, 145-175, 2003.

Flowers, T. J. and Colmer, T. D.: Salinity tolerance in halophytes, New Phytologist, 179, 945-963, 2008.

Francisco, A. M., Díaz, M., Romano, M., and Sánchez, F.: Descripción morfoanatomica de los tipos de glándulas foliares en el mangle blanco Laguncularia racemosa (L.) Gaertn, Acta Microsc., 18, 237-252, 2009.

Galue, N. and Nucette, E.: Diagnóstico de los manglares Venezolanos región Zuliana, M.A.R.N.R., Serie de informes científicos, Zona 5/IC/14, Maracaibo, Venezuela, 116 pp., 1982.

JMP: Statistics and graphics guide, Version 5: SAS Institute Inc., Cary NC, USA, 2002.

Killingbeck, K. T.: Nutrients in senesced leaves: keys to the search for potential resorption and resorption proficiency, Ecology, 77, 1716-1727, 1996.

LECO Corp.: Carbon, Nitrogen and Sulfur in Plant Tissue, Organic Application Note: CNS-2000 (form No. 202-821-172), 2003.

Lin, Y. M. and Sternberg, L. S. L.: Nitrogen and phosphorus dynamics and nutrient resorption of Rhizophora mangle leaves in South Florida, USA, Bull. Mar. Sci., 80, 159-169, 2007.

Lin, P. and Wang, W.: Changes in the leaf composition, leaf mass and leaf area during leaf senescence in three species of mangroves, Ecol. Eng., 16, 415-424, 2001.

Lugo, A. E., Medina, E., Cuevas, E., Cintrón, G., Laboy-Nieves, E. N., and Schäffer-Novelly, Y.: Ecophysiology of a fringe mangrove forest in Jobos Bay, Puerto Rico, Carib. J. Sci., 43, 200219, 2007.

Marschner, H.: Mineral Nutrition of Higher Plants, 2nd Edition, Academic Press Limited, 889 pp., 1995.

Medina, E., Giarrizzo, T., Menezes, M., Carvalho Lira, M., Carvalho, E. A., Peres, A., Silva A., Vilhena, R., Reise, A., and Braga, F. C.: Mangal communities of the "Salgado Paraense": ecological heterogeneity along the Bragança peninsula assessed through soil and leaf analyses, Amazoniana, 16, 397-416, 2001.
Medina E., Cuevas E., and Lugo, A. E.: Nutrient relations of dwarf Rhizophora mangle L. mangroves on peat in eastern Puerto Rico, Plant Ecol., 207, 13-24, 2010.

Page, A. L.: Methods of Soil Analysis - Part 2: Chemical and Microbiological Properties N0, 31-2/2/31-3, 2nd Edition, Madison Wisconsin, USA, American Society of Agronomy Inc., 1159 pp., 1982.

Reed, S. C., Townsend, A. R., Davidson, E. A., and Cleveland C. C.: Stoichiometric patterns in foliar nutrient resorption across multiple scales, New Phytologist, 196, 173-180, 2012.

Scholander, P. F.: How mangroves desalinate seawater, Physiol. Plant, 21, 251-261, 1968.

Scholander, P. F., van Dam, L., and Scholander, S. I.: Gas exchange in the roots of mangroves, Am. J. Bot., 42, 92-98, 1955.

Scholander, P. F., Hammel, H. T., Hemmingsen, E. A., and Garey, W.: Salt balance in mangroves, Plant Physiol., 37, 722-729, 1962.

Schulte, E. E.: Digestion of plant tissue for analysis by ICP Emission Spectroscopy, Comm. Soil Sci. Plant Analysis, 16, 943-958, 1985.

Sobrado, M. A.: Influence of external salinity on the osmolality of xylem sap, leaf tissue and leaf gland secretion of the mangrove Laguncularia racemosa (L.) Gaertn, Trees, 18, 422-427, 2004.

Soto, M.: Estudio florístico y estructural del bosque de manglar ubicado en la Laguna de las Peonías, ICLAM Maracaibo Edo. Zulia, 1996.

Tomlinson, P. B.: The Botany of Mangroves, Cambridge Tropical Biology Series, Cambridge University Press, Cambridge, 1986.

van Heerwarden, L. M., Toet, S., and Aerts, R.: Current measures of nutrient resorption efficiency lead to a substantial underestimation of real resorption efficiency: facts and solutions, Oikos, 101, 664-669, 2003.

Vergutz, L., Manzoni, S., Porporato, A., Ferreira Novais, R., and Jackson, R. B.: Global resorption efficiencies and concentrations of carbon and nutrients in leaves of terrestrial plants, Ecol. Mon., 82, 205-220, 2012.

Wang, W.-Q., Wank, M., and Ling, P.: Seasonal changes in element contents in mangrove element retranslocation during leaf senescence, Plant Soil, 252, 187-193, 2003. 